\title{
Exploring Networked Project Coordination in Combined Utility Streetworks
}

\author{
Léon L olde Scholtenhuis ${ }^{1 *} \oplus$, Timo Hartmann ${ }^{2}$, and André G Dorée ${ }^{1}$ (1)
}

\begin{abstract}
Combined utility streetworks involve cable and pipeline owners and authorities that concurrently undertake work in the same physical space. In this networked project setting, ownership fragmentation and lacking formal coordination instruments complicate the integration of multi-stakeholder engineering and construction operations. Boundary spanners have a unique position to pursue integration in this complex system. To understand what it is that constitutes their practices, we explore them through Mintzberg's seminal framework of informational, interpersonal, and decisional roles. Specifically, we extend the framework to the context of boundary spanning in networked projects by conducting semi-structured interviews with seven boundary spanners of combined utility streetworks: the so-called utility coordinators. Based on open coding of the interview data, we identified 149 performed activities, and twenty-three lower-level management roles (such as involving stakeholders; facilitating formal processes; and, creating a collective memory). Next, axial coding allowed us to tailor Mintzberg's role model to networked project settings. Based on this, we reflect on how a setting that lacks formal coordination instruments influences the roles that boundary spanners adopt. This empirical study of coordination in networked projects contributes a case to the practice turn literature that calls for explorations of everyday organizational practices in their situated context. Other contributions are the extension of Mintzberg's framework to networked projects; and, the development of two hypotheses about the position and roles of utility coordinators. Eventually, our findings may help practitioners identify what interpersonal and informational skills they need to improve alignment in loosely connected project networks.
\end{abstract}

\section{Keywords}

utility streetworks, networked coordination, boundary spanning roles, Mintzberg

\footnotetext{
${ }^{1}$ Faculty of Engineering Technology, Department of Construction Management and Engineering, University of Twente, Enschede, The Netherlands, 1.1.oldescholtenhuis@utwente.nl (Corresponding Author)

${ }^{2}$ Department for Civil Systems Engineering, Technical University Berlin, Civil Engineering Institute, Berlin, Germany
} 


\section{Introduction}

The utility sector buries $480,000 \mathrm{~km}$ of cables and pipelines per annum, globally (Najafi, 2005). Many of them are co-located beneath busy public streets. The limited access to these services often necessitates that a network owner combines her streetworks with other network owners. During this process, they reconstruct and maintain their assets concurrently while pavements are broken up for excavation. Combined streetworks take place amid cities, and thus require suspension of existing services such as water, gas, and electricity. To avoid delays and overruns, the public pushes authorities to safeguard that streetworks are executed efficiently.

Compared to other infrastructures such as, for example, pavement renovation or railway construction, combined utility streetworks have a more fragmented organisational context. This fragmentation is by and large an outcome of the sector's prior privatisation where state-owned utility companies were transferred to (semi) private owners. In addition, countries' liberalisation policies welcomed new firms to the utility sector and increased the number of buried assets and infrastructure owners. As a result, streetworks nowadays involve multiple client organisations instead of only one. Within this dispersed landscape of owners, specialist contractors are hired to execute the actual maintenance and construction work (Winch, 2014). The multiple clients and contractors in such projects execute work concurrently in the same physical space and create a network of physically interdependent, yet formally independent, project organisation hierarchies.

Construction management literature shows that stakeholder alignment in conventional interorganisational projects is already challenging. Cross-organisational working is, for example, historically held as a major factor for poor communication, and fragmentation in construction (Bresnen, 2007). Combined utility streetworks are one extreme form of cross-organisational working, and are, therefore, no exception to this alignment challenge. Specifically, combined utility streetworks are different from single-client construction project organisations since they neither have formal governance contracts nor do they have a nominated main principal that can align various involved project organisation hierarchies. Essentially, they are thus loose collections of client organisations that own distinctive types of buried infrastructures; set different maintenance priorities; and, have distinctive construction planning goals. These differences create a marginal goal alignment and significantly complicate stakeholder coordination.

Misalignment in utility streetworks results in ineffective coordination; difficulties for authorities to take ownership over these projects; and, adversarial relationships (Hussain et al., 2016). Often, it also leads to the underestimation of the amount of required utility replacement work, and the complexity of interfaces between interweaving cables and pipelines. In the case of the Sydney Light Rail project, for example, the underestimation of the work required to move power cables substantially increased the projects' construction costs (Saulwick, 2014). Similar hiccups occurred during the Edinburgh Tram project (Love et al., 2017). Combined utility streetworks are thus hard to accomplish on time and within budget (Vilventhan and Kalidindi, 2016). In the United Kingdom only, streetworks cause additional social-economic, and environmental costs of up to 5.1 billion GBP annually (Burtwell et al., 2006).

The outlined context of combined utility streetworks is an example of contemporary management in multi-organisational networks, where informal behaviour plays an increasingly important role in stakeholder alignment. Normally, both formal and informal coordination mechanisms are complementary in project stakeholder management (Bresnen and Marshall, 2002; Bygballe et al., 2015; Urup and Koch, 2014), and have a positive effect on inter-organisational performance and opportunism reduction (Cao and Lumineau, 2015).

Formal mechanisms and open communication practices contribute to collaborative behaviour (Aagaard et al., 2015; Clough et al., 2015; Tan et al., 2017), timely realisation, satisfactory cost performance, and achievement of project objectives (Jha and Iyer, 2007). Effectively, coordination i.e. the process of organising resources to achieve 


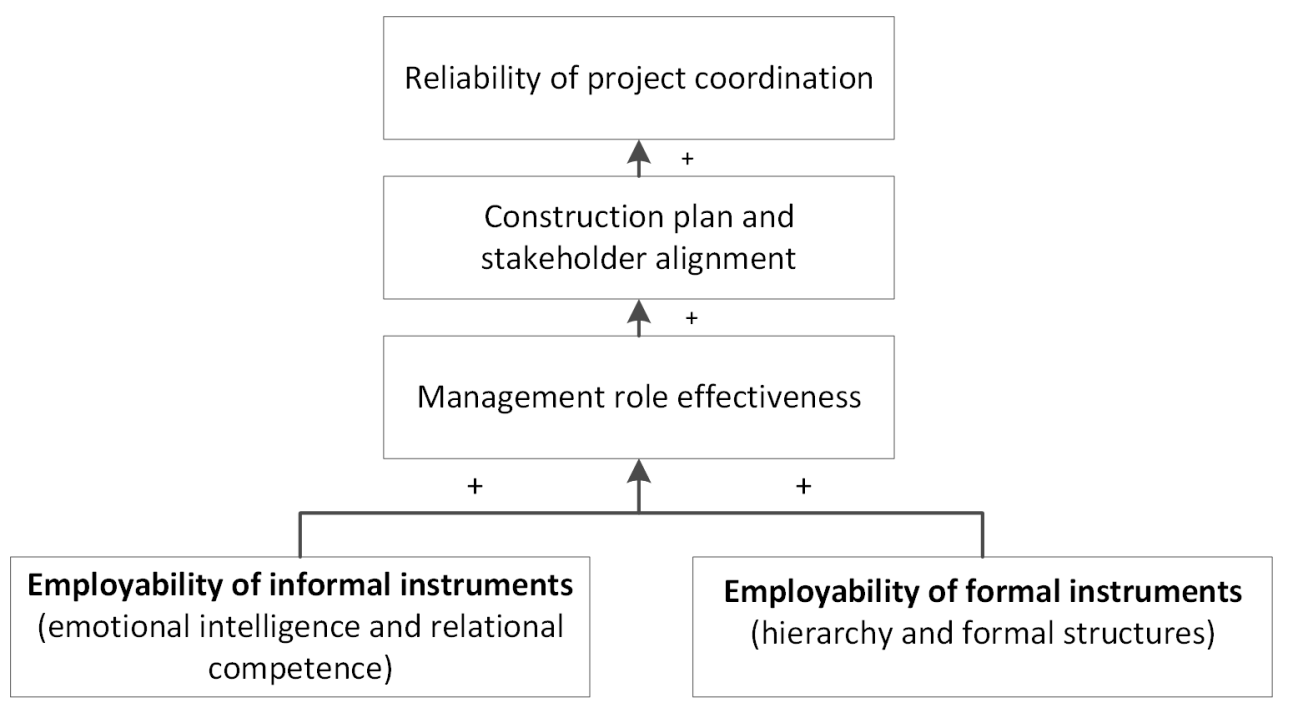

Figure 1 conceptual relation between formal and informal instruments and coordination, the effectiveness of management roles and reliability of project coordination.

enhanced operational efficiency (Hossain, 2009a) - is thus partly achieved through a clear hierarchy, formal structure, and power (Galbraith, 1977; Lawrence et al., 1967), and formal contracts (Kamminga, 2008). Additionally, alignment between organisations can be created through informal factors such as legitimacy (Anvuur and Kumaraswamy, 2012), emotional intelligence (Zhang and Fan, 2013), and relational competence (Pauget and Wald, 2013). Figure 1 illustrates the conceptual notion of a balance between formal and informal mechanisms, and its impact on the effectiveness of project management roles, construction plan alignment, and the reliability of coordination processes.

Lack of structures that align interdependent parts in network project organisations reduces the effectiveness of project teams (Chinowsky et al., 2011). What follows from this is that a project context that lacks formal instruments may need to rely more heavily on informal structures to align its stakeholders still effectively. This challenging situation exists in, for example, distributed global project organisations (Iorio and Taylor, 2015). Similarly, utility streetworks form distributed and loosely linked networks of project organisations. The alignment of such networked project organisations seems to require role sets - i.e. the sets of recurring behaviours that are appropriate to a position in a social system (Polzer and Nicholson, 1995 , p. 495-498) - that differ from the traditional organisational roles.

The Dutch utility sector is a domain that introduced such alternative roles for alignment in contemporary networked project settings. Clients and contractors in this sector introduced the job of utility coordinator to align physically interrelated, yet formally fragmented, streetworks processes. Utility coordinators are intra-organisational agents that are involved during the planning and execution stages of combined utility streetworks. Their goal is to align all distinctive operational processes that co-occur onsite. Formally, this person is employed by one utility network owner or authority. Combined utility streetworks typically involve one coordinator per construction site, and can be appointed by any utility owner or infrastructure in a region. Although they are formally employed by one organisation - such as, for example, authorities, engineering firms, and utility network owners - stakeholders commonly expect that coordinators represent the collective interests of all the utility owners in a networked project. Despite this expectation, however, network owners often do not formally mandate coordinators to represent their interests during project meetings. To still pursue alignment between the network of stakeholders, 
coordinators, therefore, need to perform informal tasks like identifying and mobilising stakeholders involved in streetworks; assessing interactions between them; identifying process bottlenecks; and, exchanging project information.

The theoretical concepts of systems integrators and boundary spanners describe activities that contribute to alignment in networked project settings. This literature focuses on network structures and personality traits of strategic managers in innovation processes and new product development (Chinowsky and Taylor, 2007). By the nature of their work, utility coordinators can be considered as a boundary spanner between road authorities, distinctive utility network owners, and contractors. In contrast with boundary spanners in the existing literature - that span across one internal and various external organisations utility coordinators bridge voids between multiple organisational hierarchies in a networked project setting. The literature would, therefore, benefit from an exploration of this challenged and exceptional context. One way to do this is by developing detailed empirical descriptions of the actual behaviour of the boundary spanners in utility streetworks. This study, therefore, interviewed utility coordinators and identified their work practices. To conceptualise their behaviour, we adopted the model of Mintzberg $(1973,1990)$ and its concepts of informational, interpersonal, and decisional roles. We used these to formulate refined roles that describe boundary spanner work and to assess the influence of a contemporary networked context on the adoption of specific boundary spanning roles.

The remainder of this paper is structured as follows: the next section outlines the theoretical points of departure. It elaborates on boundary spanning and the management roles that we used as a lens for our study (Mintzberg, 1973, Mintzberg, 1990). We then explain how we verified and refined the management roles after conducting semi-structured interviews. Next, we describe the study outcomes and conclude by discussing implications and formulating directions for future research on combined utility streetworks coordination.

\section{Theoretical Starting Points for Studying Coordination in the Utility Construction Sector}

Combined utility streetworks are structurally not just one integrated project but a set of multiple individually organised project entities. This setting can be described by the term 'networked project' (Chinowsky et al., 2010). In networked projects, related individuals and organisations collaborate within the scope of several projects (Manning, 2005). In contrast with conventional project organisations - which control mainly through mechanisms such as hierarchy (Sherman and Keller, 2011; Tsai, 2002) and contracts (Wang et al., 2017) - coordination in networked projects relies more on interpersonal information communication, and social mechanisms (Bechky, 2006; Hodgson, 2004; Hossain, 2009b; Pauget and Wald, 2013). We discuss below how networked projects can be seen as systems that integrate through boundary spanning. Next, we posit that Mintzberg's framework of management roles can be applied to this context to better understand the influence of institutional environments (i.e., formal and informal coordination mechanisms) structures on boundary spanning work.

\section{Intra-Organizational Alignment Through Systems Integration and Boundary Spanning}

Existing studies explore project-based network organisations (Davies and Brady, 2016) and their alignment (Miterev et al., 2017), and elaborate on what strategic mechanisms exist to enable intraorganisational coordination (Davies and Brady, 2000). In the context of product development, systems integrators, for example, perform integrative activities between members of an innovation network. They use high-level business, control, cooperation, and development-oriented mechanisms (Momeni and Martinsuo, 2019), and interact with suppliers during meetings, training, co-location, and joint efficiency-seeking activities (Ahola et al., 2017). Systems integrators have managerial knowledge, experience, and skills to coordinate and execute activities that, in turn, result 
in the achievement of stakeholders' shared goals (Davies and Brady, 2016). System integration goals often have a long-term strategic character such as, for example, the development of new products (Ahola et al., 2017) and construction megaprojects (Davies and Mackenzie, 2014).

One type of individual that has a unique structural position in a network to fulfil systems integration tasks, is a boundary spanner. Boundary spanning agents are formal members of an organisation that liaise strategically with externals (Brion et al., 2012; Lee and Sawang, 2016) while acting on behalf of their own organisation (Ahola et al., 2017; Brion et al., 2012). In collaborative networks, this individual brings disparate groups - i.e. that have no formal basis of trust into one another - together to allow them to work more effectively (Long et al., 2013). To align disparate groups in inter-organisational project settings relational dynamics play a major role (Larson and Wikström, 2007).

Existing studies explicated the communication patterns of boundary spanners using social network analyses (Chinowsky and Taylor, 2012) to show how they acquire a position in an informal network. Studies also show that interaction frequency influences a boundary spanners' position (Lee and Sawang, 2016). These interactions include activities such as gaining technical inputs, coordinating stakeholders, obtaining support from top managers (Tushman and Katz, 1980), obtaining political support, scanning for novel ideas (Brion et al., 2012; Joshi et al., 2009), and revolving tensions and intercultural dynamics (Di Marco et al., 2010; Stjerne et al., 2019). Boundary spanners also use project artefacts (such as virtual design models) to mediate between the boundaries of stakeholder disciplines (Iorio and Taylor, 2014).

Essentially, boundary spanning enables individuals to bridge across technical and knowledge boundaries (Zelkowicz et al., 2015). Literature traditionally conceives the boundary spanner as an individual that has the structural position and role-set to bridge between one internal and several external organisations. When extended to the networked project context, however, the concept of boundary spanning could also lend itself to identify and analyse informal and relational alignment activities between multiple project organisations in a network.

\section{Call for Practice-Based Studies of Or- ganizational Work in Situated Contexts}

To develop an understanding of the boundary spanning activities, the literature proposes to look at their work as organisational 'practices'. Practices are the situated and routine - rather than abstract processes and skills that people use when working with the resources they have in their everyday life (Certeau, 1984; Whittington, 2003). The need for deeper exploration of what individuals actually do every day emerged from practice-based studies in organisation science. This stream of literature calls for a better understanding of the functionality of organisations by creating insights about the daily micro-practices of individuals, in and around the office space (de Holan and Mintzberg, 2004). Rather than focusing on the generalisation of management categories, the practice turn inspires the study of everyday work and develops a richer empirically-based understanding (Korica et al., 2017).

Strategy-as-practice studies, for example, consider individuals as the interpreters of practices as they study 'lived moments' of individuals in systems and societies (Whittington, 2006). They investigate how the work of strategizing is 'actually done' in empirical practical realities (Whittington, 2003), by conducting, for example, narrative analysis of people that develop and use strategy (Fenton and Langley, 2011). Other applications of practice studies are in the domains of organising innovation (Dougherty, 1992), organising technology (Orlikowski, 2000), and organisational learning (Brown and Duguid, 2001). Also in construction management, practice turn-inspired studies are likely to contribute to the understanding of different working practices in organizationally diverse teams (Bresnen, 2007).

\section{Mintzberg's Role Model: A Framework for the Exploration of Boundary Span- ning in Networked Projects}

Seminal to the practice turn is the work of Mintzberg. This work provided the prospect of 
roles in an organisation (Burström and Jacobsson, 2013).

Second, the central position that managers acquire through their interpersonal role allows them to become nerve-centres in organisations (Mintzberg, 1973, p. 666666), and to coordinate the activities of others within the network (Hossain, 2009a). This position shapes the informational roles of the monitor, disseminator, and spokesperson. Monitors scan the environment for information that influences organisational performance; disseminators spread information to subordinates and colleagues that otherwise have no access to it; and, spokespersons communicate information to external stakeholders that influence processes in the organisation. The monitor role strengthens the position of the manager as it puts him in at the central place of communication between stakeholders (Chinowsky et al., 2010). It allows him to keep the project organisation together (Blackburn, 2002; Ozorovskaja et al., 2007).

Third, informational roles facilitate decision making. Mintzberg $(1973,1990)$ defined four decisional roles: entrepreneur, disturbance handler, resource allocator, and negotiator. Decision making roles are necessary to control critical path activities and budgets, and in taking corrective actions (Jha and Iyer, 2006). Entrepreneurs seek improvement and try to adapt the organisation to changing conditions in the environment. Next, as coordination needs may result from unexpected events (Bygballe et al., 2016) disturbance handler roles exist to cope with unexpected situations that lie outside managers' regular work processes. Finally, the resource handlers decide how the organisation allocates and authorises budget, manpower, equipment, and time; and, negotiators discuss contracts and solve problems with individuals and other organisations.

In essence, the original interpersonal, informational, and decisional role categories define the behaviour of managers within one single organisation. Yet, in the inter-organisational context of combined utility streetworks, privatisation has splintered ownership of utility networks from a single authority to myriads of public and private organisations, fragmenting the public infrastructure sector as a whole (Steenhuisen et al., 2009; de Bruijne and van Eeten, 2007). Compared 
Table 1 column 1: role categories, column 2: summary of management roles after Mintzberg $(1973,1990)$, column 3: adapted role definition for networked project boundary spanning

\begin{tabular}{|c|c|c|}
\hline RolelUnit & single organisational & networked projects \\
\hline \multirow[b]{3}{*}{ Interpersonal } & a figurehead conducts ceremonial duties & $\begin{array}{l}\text { as a figurehead, a coordinator facilitates but } \\
\text { does not perform ceremonial duties }\end{array}$ \\
\hline & $\begin{array}{l}\text { a leader performs direct leadership by hiring } \\
\text { and training subordinates as well as by } \\
\text { criticising, encouraging, and motivating them }\end{array}$ & a coordinator does not perform leadership roles \\
\hline & $\begin{array}{l}\text { a liaison maintains contact with people that } \\
\text { stand outside his vertical chain of command }\end{array}$ & $\begin{array}{l}\text { a coordinator liaises as a central person between } \\
\text { distinctive project organisations in the network } \\
\text { by facilitating contact, activating stakeholders, } \\
\text { signalling hiccups, and discussing construction } \\
\text { plans }\end{array}$ \\
\hline \multirow[b]{3}{*}{ Informational } & $\begin{array}{l}\text { a monitor perpetually scans the environment for } \\
\text { information that influences the processes within } \\
\text { the organisation directly or indirectly }\end{array}$ & $\begin{array}{l}\text { a coordinator scans for information at the } \\
\text { construction site that may obstruct the process } \\
\text { consults clients and contractors and assures } \\
\text { safety }\end{array}$ \\
\hline & $\begin{array}{l}\text { a disseminator passes information from one } \\
\text { stakeholder to the other }\end{array}$ & $\begin{array}{l}\text { a coordinator passes information, serves as } \\
\text { a collective memory for the stakeholders by } \\
\text { making and exchanging information }\end{array}$ \\
\hline & $\begin{array}{l}\text { a spokesperson informs and satisfies influential } \\
\text { people, and sends information to people outside } \\
\text { the unit }\end{array}$ & $\begin{array}{l}\text { a coordinator does not actively fulfil a strict } \\
\text { spokesperson role but tries to satisfy public } \\
\text { stakeholder values during meetings }\end{array}$ \\
\hline \multirow[b]{4}{*}{ Decisional } & $\begin{array}{l}\text { an entrepreneur attempts to adapt his } \\
\text { organisation to changing conditions in the } \\
\text { environment }\end{array}$ & $\begin{array}{l}\text { a coordinator does not perform entrepreneurial } \\
\text { roles }\end{array}$ \\
\hline & $\begin{array}{l}\text { a disturbance handler responds to pressures that } \\
\text { threaten ongoing processes }\end{array}$ & $\begin{array}{l}\text { a coordinator formally does not enforce } \\
\text { decisions but actively facilitates permitting } \\
\text { procedures, and the troubleshooting of } \\
\text { operational and design issues }\end{array}$ \\
\hline & $\begin{array}{l}\text { a resource allocator decides how to distribute } \\
\text { resources such as time, money, and labour }\end{array}$ & $\begin{array}{l}\text { a coordinator does not decide how resources } \\
\text { are distributed but provides advice to network } \\
\text { stakeholders }\end{array}$ \\
\hline & $\begin{array}{l}\text { a manager performs negotiations on behalf of } \\
\text { his unit }\end{array}$ & $\begin{array}{l}\text { a coordinator does not have negotiation } \\
\text { authority }\end{array}$ \\
\hline
\end{tabular}

to the already fragmented construction industry, where the performance of a project depends on the performance of its interrelated stakeholders (Fellows and Liu, 2012), interfaces between combined utility streetworks seem therefore even more complex to manage. Mintzberg's implicit focus on roles within a single organisational hierarchy implies that both formal and informal mechanisms are in place to successfully align stakeholders. However, in the context of networked project settings - such as combined utility streetworks - formal mechanisms are lacking. This may render some role types obsolete, require new roles, or necessitate changes to existing roles.

From the above, it shows that boundary spanners have a unique position and role-set to fulfil a systems integration task. Further, the literature calls for more empirical studies of organisational micro-practices in context. The framework of Mintzberg $(1973,1990)$ focuses on 'what managers actually do'. Since it includes a variety of roles that are empowered by formal and 
informal mechanisms, the framework provides a pragmatic starting point for empirical studies of boundary spanning in networked projects. The goal of this study is, therefore, to extend Mintzberg's framework to the context of boundary spanning in networked projects. Specifically, we use the framework as a lens to identify and refine coordination roles, and to assess what influence the lack of formal coordination mechanisms in a networked project context has on the adoption of boundary spanning roles.

\section{Method}

Western countries' privatisation policies fragmented utility ownership and shaped a sector in which multiple owners and clients organise combined streetworks. The Netherlands is one such area and forms the context for this study. In this country, utility coordinators are mobilised as managers that align the various project entities that concurrently work to reconstruct buried infrastructures. We use the explorative practicebased approach to extend knowledge about boundary spanning in this situated setting. We selected the specific case of utility coordination and identified a small respondent group for a grounded exploration (Strauss and Corbin, 1990) of their boundary spanning activities. We interviewed the utility coordinators about their behaviour and subsequently used Mintzberg as a lens to develop and refine coordination role categories.

As the first step, we identified interviewees. The utility coordinator is not a registered profession in the Netherlands. This role is ill-defined in practice, and the job titles related to the function differ between organisations. To identify respondents we, therefore, used snowball sampling. This means that we asked participating respondents to suggest potential interviewees that had similar job profiles as theirs. Table 2 shows that we found eight coordinators, each employed by a different organisation. All respondents executed their job for at least four years. We expect based on the geographical spread of our respondents, that the Netherlands has around thirty utility coordinators. Except for the two persons that often worked as a team (interview 3), respondents were interviewed individually. The interviews had an average duration of 81 minutes, with a minimum of 38 and a maximum of 123 minutes.

To collect data, we combined an open-ended interview approach with elements of ethnographic interviewing. Ethnographic methods are used to obtain a thick description of the elements that constitute a practice. Ethnographic interviewing is a non-participatory method that has a short involvement with the subject of interest (Oswald and Dainty, 2020). The method allowed us to explore the variety of boundary spanning roles

Table 2 descriptive information about the interview respondents

\begin{tabular}{|l|l|l|l|l|l|}
\hline Interview & Job title & $\begin{array}{l}\text { Education } \\
\text { level }\end{array}$ & $\begin{array}{l}\text { Experience } \\
\text { (years })\end{array}$ & Employer & Work domain \\
\hline $\mathbf{1}$ & Utility coordinator & Vocational & 17 & Water provider & Local infrastructure \\
\hline $\mathbf{2}$ & $\begin{array}{l}\text { Utility coordinator third } \\
\text { parties }\end{array}$ & MSc. & 16 & Freelance & $\begin{array}{l}\text { National or regional } \\
\text { infrastructure }\end{array}$ \\
\hline $\mathbf{4}$ & Utility coordinator & Vocational & 4 & Utility contractor & Local infrastructure \\
\hline $\mathbf{3}$ & $\begin{array}{l}\text { Utility coordinators } \\
(2 \text { respondents })\end{array}$ & Vocational & 9,4 & Water provider & Local infrastructure \\
\hline $\mathbf{5}$ & $\begin{array}{l}\text { Utility coordinator third } \\
\text { parties }\end{array}$ & MSc. & 5 & $\begin{array}{l}\text { Engineering } \\
\text { consultancy }\end{array}$ & $\begin{array}{l}\text { National or regional } \\
\text { infrastructure }\end{array}$ \\
\hline $\mathbf{6}$ & $\begin{array}{l}\text { Utility coordinator third } \\
\text { parties }\end{array}$ & Vocational & 13 & Consultancy & $\begin{array}{l}\text { National or regional } \\
\text { infrastructure }\end{array}$ \\
\hline $\mathbf{7}$ & Advisor cables and pipes & MSc. & 12 & Municipality & Local infrastructure \\
\hline
\end{tabular}


from the insider-viewpoint of a coordinator. Our ethnography inspired questions focused on obtaining descriptions of the everyday experience of the practitioners being interviewed (Bauman and Adair, 1992; Cicmil et al., 2006). Two key components of the interviews were grand and minitour questions (Spradley, 1979). Examples of grand tour questions were: can you describe step-by-step how you coordinate a typical utility project? Can you please describe the main activities that you perform during a regular work week? Examples of mini-tour questions are: can you explain why you do this particular step? And could you provide a detailed description of such a meeting? Besides these questions, we asked respondents to complete their descriptions of their work by elaborating how they feel coordination should be executed properly. This resulted in extensive descriptions of respondents' everyday activities and their contexts.

As a next step, we transcribed our interviews and analysed these by using the qualitative data analysis tool ATLAS.ti. This started with steps of grounded theorising through open coding and it continued with axial coding (Strauss and Corbin, 1990). Figure 2 shows our three coding rounds. Given the unique and unexplored character of combined utility streetworks, we first analysed interview data without consulting literature. In the first round, we hence coded raw data by going through the transcripts line-by-line. This open coding step helped us familiarise ourselves with the data in a structured way. As an outcome, we identified 149 verbatim quotes that described the boundary spanning practices of our respondents.
Second, we used axial coding to further develop our concepts based on the literature. Mintzberg's three role types helped us during this step to cluster 149 quotes into 12 management roles (see Table 1 column 1 and 2). We refer to the outcomes of this categorization as first-tier codes. In the third round, we went through the transcripts again to further break down first-tier codes. This resulted in 23 second-tier codes that describe the management roles of a utility coordinator in the greatest detail. As the last step, we refined or removed the first-tier codes from Mintzberg's original framework in case we did not find support for those in the data.

\section{Result}

Table 3 provides a summary of the outcomes of the first two coding rounds. Based on the initial framework of Mintzberg $(1973,1990)$, it presents an overview of the identified boundary spanning activities. In specific, columns one and two describe the original role types and first-tier codes from Mintzberg $(1973,1990)$. The remaining columns (entitled nr. $1-$ nr. 7 respectively) show the frequency by which a role occurred in the practices of our respondents.

Table 3 shows that the observed instances of utility coordinators' activities are distributed unequally between the first-tier codes. Most observed activities relate to informational (INF) and interpersonal (INP) roles. Examples are monitoring, disseminating, and liaisoning. Roles such as disturbance handler, leader, criticizer,

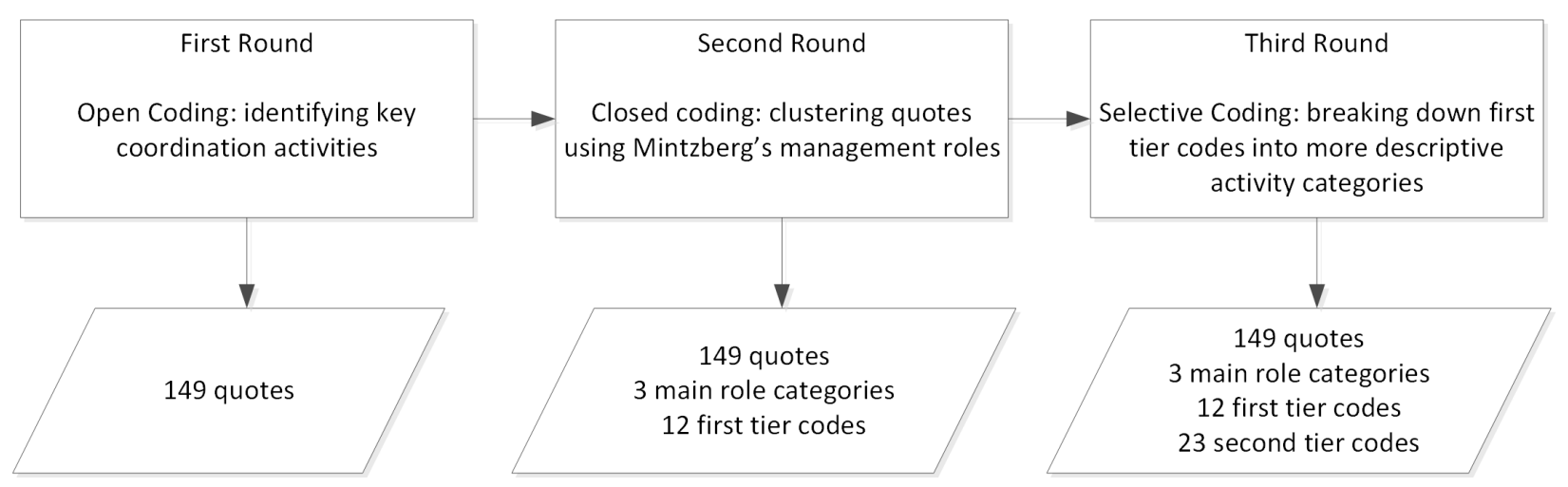

Figure 2 visualisation of the three-staged coding process and its outcomes.

Engineering Project Organization Journal

(C) 2021 Engineering Project Organization Society www.epossociety.org 
Table 3 summary of identified instances of interpersonal (INP), informational (INF), and decisional (DEC) activities

\begin{tabular}{|l|l|l|l|l|l|l|l|l|c|}
\hline Roles & First-tier codes & $\mathbf{1}$ & $\mathbf{2}$ & $\mathbf{3}$. & $\mathbf{4}$ & $\mathbf{5}$ & $\mathbf{6 .}$ & $\mathbf{7 .}$ & SUM \\
\hline \multirow{5}{*}{ INP Leader } & Direct leadership & 1 & 1 & 0 & 0 & 2 & 1 & 0 & $\mathbf{5}$ \\
\cline { 2 - 11 } & $\begin{array}{l}\text { Criticise, motivate encourage, } \\
\text { train }\end{array}$ & 3 & 2 & 2 & 1 & 4 & 0 & 1 & $\mathbf{1 3}$ \\
\hline INP Liaison & Contact outside comm. chain & 4 & 3 & 7 & 3 & 2 & 2 & 4 & $\mathbf{2 6}$ \\
\hline INP Figurehead & Conduct ceremonial duties & 1 & 1 & 2 & 1 & 1 & 0 & 1 & $\mathbf{8}$ \\
\hline INF Monitor & Scan environment & 7 & 9 & 5 & 6 & 4 & 3 & 1 & $\mathbf{3 8}$ \\
\hline INF Disseminator & Pass information & 4 & 3 & 9 & 3 & 5 & 0 & 2 & $\mathbf{2 2}$ \\
\hline INF Spokesperson & Inform and satisfy & 1 & 0 & 0 & 1 & 0 & 2 & 0 & $\mathbf{4}$ \\
\hline & Send info outside unit & 0 & 0 & 0 & 1 & 0 & 0 & 3 & $\mathbf{5}$ \\
\hline DEC Entrepreneur & Adapt to environment & 0 & 0 & 0 & 0 & 0 & 0 & 0 & $\mathbf{0}$ \\
\hline DEC Disturbance handler & Respond to pressures & 5 & 4 & 2 & 2 & 3 & 2 & $\mathbf{1}$ & $\mathbf{1 7}$ \\
\hline DEC Resource allocator & Allocate resources & 1 & 3 & 0 & 1 & 0 & 0 & $\mathbf{2}$ & $\mathbf{7}$ \\
\hline DEC Negotiator & Negotiate & 2 & 0 & 0 & 0 & 1 & 0 & $\mathbf{1}$ & $\mathbf{4}$ \\
\hline & & & & & & & & & $\mathbf{1 4 9}$ \\
\hline
\end{tabular}

and figurehead were found less often. Resource allocator, spokesperson, direct leadership, and negotiator roles were identified the least frequently. We did not find an instance of entrepreneurial behaviour. The remainder of this section breaks down the first-tier codes from Table 3 into secondtier codes and presents selected verbatim quotes to illustrate each code in detail.

\section{Interpersonal Activities}

Table 4 shows the identified work activities with the traditional role descriptions of leader, liaison, and figurehead. The first and second columns show the theoretical roles and first-codes. The third column contains the developed second-tier codes

Table 4 interpersonal roles; and corresponding activities from theory (first-tier) and interview data (second-tier)

\begin{tabular}{|l|l|l|}
\hline Role & First-tier code & Second-tier code \\
\hline Leader & Criticise, encourage, motivate, and train & \\
\hline & Direct leadership & \\
\hline Liaison & Contact outside the chain of command & Facilitate contractor collaboration \\
\hline & & Facilitate information passing \\
\hline & & Signal potential hiccups \\
\hline & & Activate stakeholders \\
\hline & & Play a central role \\
\hline & & Identify and involve stakeholders \\
\hline & & Discuss the proposed plans \\
\hline Figurehead & Conduct formal ceremonies & Facilitate formal processes \\
\hline
\end{tabular}


that describe the utility coordinators' everyday tasks more precisely.

First, utility coordinators adopted elements of leadership roles in ways that they 'criticise, encourage, motivate, and train' the clients, contractors, and peers during the management of utility streetworks processes. They give feedback on designs and construction plans and teach novice project managers on how to align interfaces between construction plans. Although coordinators are no formal clients, they show leadership in activities such as preparing permits, designs, and construction plans. One example of performed leadership is given by the verbatim quote below. In this quote, two coordinators explain that engineers sometimes make design errors because they do not sufficiently explore the project environment before works start. The coordinators argue that, in such situations, they conduct additional site inspections themselves to comment on the earlystage designs and avoid errors of contractors and utility companies:

"So [the engineer] just makes a design and [...] he explains that the cable can be moved over [to an empty trench located close by] without any problems. But sometimes the technicians in the field find out that the proposed design is not feasible at all. These situations are difficult [to resolve], so we [coordinators] try to prevent them."

Respondents also explained that they perform leadership roles when stakeholders are indecisive as to how they should integrate construction plans. This happens, for example, when information is incomplete; the status of tasks assigned to stakeholders is unclear; and, when stakeholder interests conflict. In the quote below, a coordinator explains that he aims to avoid such situations but that he sometimes tries to lead processes by enforcing a decision:

"You do not have to interfere if they all agree. And as a coordinator, you need to learn how to get the people adopting the same line. You need to avoid that they let situations become too ambiguous [or adversarial]. Otherwise, you become a police officer that needs to mediate between them. [However, when push comes to shove, we prescribe a solution and argue that] we will do it like that!"

Second, the liaison role was visible in the activities related to the first-tier codes of 'contacting outside the chain of command' and 'direct leadership'. Utility coordinators use this liaison role because they do not work in a single organisational hierarchy but operate between multiple project organisations at the same time. Specifically, the alignment in the networked setting requires (1) coordination within each project organisation hierarchy (e.g., between a water network owner and her contractor); (2) lateral coordination between distinctive network owners (e.g., between water and telecoms network owners), and (3) lateral coordination between distinctive contractors onsite (e.g., between the water contractor and the telecoms network contractor). Our data shows that this is mostly facilitated by a liaison role while coordinators perform activities such as: identifying and involving relevant stakeholders in the network; organising stakeholder meetings to facilitate the integration of construction plans; making sure that the different clients and contractors work with updated versions of design sections and maps; signalling potential process hiccups when plans derail; activating stakeholders to accelerate their work in case deadlines are not met; and, being the projects' central memory of historical project events.

Related to the identification of stakeholders in the network, for example, a coordinator explained that he was the only person who had an overview of all the utility company representatives in a project area. He, therefore, knew who to involve for planning and construction operation alignment. This information allowed him to get stakeholders together to organise meetings, communicate minutes, and exchange project updates. One coordinator further argued that he had the task to manage the interfaces between the different stakeholders. The verbatim quote below shows that he, therefore, contacted contractors to verify whether they made the right efforts to integrate their parts into the master construction plan: 
"I check the drawings and see that ten utility companies are being located right there. [So] then I will check whether they have been talking to one another and check what appointments have been made.

The third interpersonal role is that of a figurehead. We did not find any instance of figurehead behaviour that resembles the original definition of Mintzberg (i.e., performing routine duties of a social or legal nature). This narrow definition implies that utility coordinators are figurehead if they present the project to external stakeholders and that they officially approve a construction plan, deliverable, or a permit. Since the utility coordinator did not have the formal mandate for any of these tasks, we re-interpret the figurehead role as follows: utility coordinators contribute to the original figurehead role to a certain extent. In broader terms, they facilitate other stakeholders that represent the distinct project organisations and perform legal routines (such as approving minutes, plans, and designs). One respondent gave an example of an activity that fits this definition. He stated that one of his tasks is to prepare a formal construction plan for each project, and to ask different utility companies to sign off this document:
"And every stakeholder needs to sign a document in which they state that they will execute the work as planned. So, at the moment that the project starts outside, my project manager and site supervisor will receive a dossier [from me] containing the descriptions of all the appointments that I made with the different utility companies."

Similarly, another utility coordinator explained that he pursues municipalities to sign off drawings because this makes the status of project drawings approved and official, enabling them to start engineering their work processes.

\section{Informational Activities}

Activities related to the informational role categories of disseminator, spokesperson, and monitor are shown in the second-tier codes and first-tier codes of Table 5. The table shows that utility coordinators executed disseminator tasks frequently by the passing of information. This included the lowerlevel role 'functioning as a collective memory'. This means that coordinators develop an archive and memory of decisions that stakeholders made and design ideas that were shared within the

Table 5 informational activities; and corresponding categories from theory (first) and interview data (second tier)

\begin{tabular}{|l|l|l|}
\hline Role & First-tier code & Second-tier code \\
\hline Disseminator & Pass information & Create collective memory \\
\hline & & Making minutes \\
\hline & & Sharing contact information \\
\hline & & Update stakeholders about progress \\
\hline Spokesperson & Inform and satisfy & Peer communication \\
\hline & Send information to the outside of a unit & \\
\hline & & Represent other's interest \\
\hline Monitor & Scan environment & Inspect construction site \\
\hline & & Consult clients \& contractors \\
\hline & & Collecting relevant project information \\
\hline & & Check process and bottlenecks \\
\hline & & Assure onsite safety \\
\hline
\end{tabular}

Engineering Project Organization Journal

(C) 2021 Engineering Project Organization Society

www.epossociety.org 
network. The selected example below illustrates this. The quote shows how coordinators develop a collective memory based on the construction plans that stakeholders send to them:

"We expect that all clients know where to be [in case they need information] and that they send all the necessary project information to us. This includes [that they send] their drawings in pdf and dwg-format"

One respondent stated that another important role for him is to update stakeholders about the progress of the project. He explained that he wants to prevent delays resulting from unexpected site conditions. Sometimes, for example, rework is caused by cables that are found unexpectedly nearby the planned location of a designed pipe. Then, redesign and required additional permitting procedures can lead to significant delays. To circumvent this, the coordinator explained that he continually tries to update agencies and officials involved to work around time-consuming formal permitting procedures.

We additionally found that the central position and knowledge about all network stakeholders enable the coordinator to have a substantial role in sharing contact information between organisations and updating them about the progress of all planning and construction work. One respondent argued that this information exchange task consumes $80 \%$ of his time.

Another informational role is that of a spokesperson. A spokesperson represents and defends the interests of an organisation. However, utility coordinators often do not represent one, but a myriad of project organisations in the networked project. Consequently, they do not necessarily act on behalf of one organisation only. The eight activities we found, therefore, correspond only to a lesser degree with the original theoretical spokesperson roles (i.e., informing and satisfying, and sending information to outside units). We did, however, find similarities with spokesperson activities when we did not take the organisational boundaries into account. The role of satisfying stakeholders was, for example, considered as one of the most important tasks of a utility coordinator. One respondent even argued that satisfying and having good contacts with utility owners, clients, and citizens are the main objectives of his job. Another spokesperson role was the exchange of information outside the project team. The explanation of the coordinator in the verbatim quote below, for example, discusses that his central role allows him to gain oversight over various project stakeholders. This, in turn, helps him to explain the impact of planned construction work to external stakeholders:
"The only thing you can do is to communicate very clearly to citizens, the environment, and companies, and to be clear on what the consequences are of the project work."

The interviews further showed that depending on the situation in which they act as a spokesperson, coordinators may represent different (clusters of) organisations. They can, for example, represent their own employer, other utility companies, authorities, or all the internal stakeholders in networked project. The following quote explains how one coordinator argues about his duty to represent multiple organisations at once, irrespective of who his formal employer is:

\section{"I always work as if the cables and pipes are my own. It is important for the utility owners to let them feel that this happens. This creates trust and goodwill since they feel that you defend their interests."}

Furthermore, utility coordinators perform a monitoring role. We identified different categories of activities. These are: visiting the construction site for inspection before the start of the project and during its execution; consulting clients and contractors for more information about design changes; collecting relevant project information such as existing utility maps; checking progress and bottlenecks (e.g., related to permits, designs); and, ensuring that safety for the construction crew is safeguarded. A construction site inspection was mentioned mostly as an executed (monitoring) activity. As shown by the following verbatim quote, such an inspection allows coordinators to monitor whether utilities are buried at the right 
Table 6 decisional activities; and corresponding categories from the theory (first tier) and interview data (second tier)

\begin{tabular}{|l|l|l|}
\hline Role & First-tier code & Second-tier code \\
\hline Entrepreneur & Adapt to environment & \\
\hline Resource allocator & Allocate resources & Plan workflow \\
\hline & & Discuss work method \\
\hline Negotiator & Negotiate & \\
\hline Disturbance handler & Respond to pressures & Solve permit \& design issues \\
\hline & & Solve operational problems \\
\hline
\end{tabular}

depth; the work situation is safe; all the drawings are in the cabin, and if any changes or problems are occurring:

"[...] Then I visit the crew. I go and have a look, for example, whether utilities are buried at the right depth. And whether the work situation is safe. The contractor arranges most of these things himself, but I still think it is important to go visit him. They have all their drawings in the cabin, and when I visit them, I can see right away whether there are problems."

\section{Decisional Activities}

Table 6 contains an overview of the roles and related decisional activities. We did not identify any example of entrepreneurial behaviour (i.e., adapting work to a changing organisational environment). Although they coordinated projects in evolving circumstances, the coordinators were not able to continually make decisions that resulted in changes to the project scope and content. Further, the remaining first-tier roles of resource allocator, negotiator, and disturbance handler were identified a few times. We elaborate on the selected examples below.

Although utility coordinators have a limited budget to decide about the project's resource allocation and construction methods, they still seem to use their position to perform resource allocation roles. Respondents state that they sometimes try to influence the type of resource that various contractors use, by proposing a range of alternative construction methods for the project. Some construction methods (such as the vacuum excavator) may, for example, be more expensive for one individual contractor but are more efficient, or less disruptive, for the project as a whole. One respondent explained about this that he tries to always propose the optimal construction methods to reduce potential damage, delays, cost overruns, and public nuisance:

"It is all taxpayers' money. My goal is to realize the project with the lowest [direct construction] costs. But sometimes you need to deviate from this and choose more expensive solutions instead. For example, in case the project has delays, [...] you should then convince others that the project needs an alternative construction technique. This may be more expensive, but it is [faster and thus] necessary [to meet the deadline and reduce excessive hindrance]"

Next, the coordinator fulfils a negotiator role by supporting negotiations within the project network. This happens, for example, when plans deviate and when stakeholders are indecisive about how to proceed. The quote shows that this happens when polluted soil is found unexpectedly, and when work is delayed:

"You will suspend the on-site work, and then the trouble starts. Sometimes you need to send away the contractor and you need to start discussions with the municipality and all other parties. To discuss how to proceed. [When there is polluted soil] cabins are

Engineering Project Organization Journal

(C) 2021 Engineering Project Organization Society www.epossociety.org 
and, maintaining interpersonal relations with utility owners and contractors. Below, we discuss these findings, address their contribution to literature, and elaborate the limitations of this study.

In the refined role model, we added lowerlevel categories (in Tables 4-6) and extended or reformulated existing role definitions. Column three in Table 1 contrasts the revised roles with the original roles from the literature. New second-tier roles were specified, for example, for the liaison, disseminator, and monitor roles. These additional roles were used in practice to informally connect between boundaries of project organisations. We further redefined the spokesperson, figurehead, entrepreneur, and negotiator roles since their original definitions require formal coordination instruments, which were missing in utility projects. Instead of defining the decision-making role based on activities such as giving directive orders, acting as a formal representative, and making decisions, we, therefore, redefined it for the networked project context as facilitating the decision-making processes by preparing meetings and making sure that permit documents are signed off and exchanged timely.

This suggested refinement resonates with observations in the boundary spanning literature. The refined facilitating decision making-role, for example, shows similarities with the context of policy implementation. Here, boundary spanners do not have the requisite authority to develop instruments and influence organisational routines. They, therefore, use their roles to translate external information into forms that other decisionmakers can access and use (Honig, 2006). This means that boundary spanners filter information. They function as a gatekeeper of information that is exchanged between various stakeholder organisations in the network. Although these roles of so-called information brokers and gatekeepers are considered essential to mediate and resolve conflict and produce collaborative environments, a negative effect can be that informational overload makes the task inefficient and overwhelming (Long et al., 2013).

Additionally, the identified coordination behaviour allowed us to draw preliminary conclusions about the frequency of employed 
boundary spanning tasks. The numbers in Table 3 are by no means a precise and definitive measure but they do give a first indication of what tasks our respondents perceived as more relevant to their everyday routines. Coordinators mostly perform informational tasks (we identified 73 instances in total) and interpersonal tasks (58), and fewer tasks related to decision making (30). Further, liaison (INP), monitor, and disseminator roles (INF) were identified most frequently (respectively 26, 38, and 22 times). The decisional roles were identified the least frequently as: the data did not reveal instances of entrepreneurial activities, and we found only four examples of negotiation.

The refined categories and the frequency of employed tasks show an imbalance between formal and informal role types in fragmented networked projects. For example, roles with decisional nature are sparser in networked project settings than may be suggested by Mintzberg's seminal framework. This may, again, be explained by the premise that combined utility streetworks lack the hierarchy and formal coordination mechanisms that normally would enable decisional activities within one organisational boundary. It seems thus that boundary spanners' lack of an acknowledged formal position in the network, makes them redefine their formal roles, and resort to a range of informational and interpersonal activities to pursue alignment.

The practice turn literature also sheds light on this finding. Specifically, Levina and Vaast (2005) draw four sources of capital from Bourdieu and Wacquant (1992, p. 119) to argue that various formal and informal capital sources enable boundary spanners to fulfil their work. Two sources of capital are economic (i.e., money, time, and technology) and symbolic (i.e., the ability to name resources as valuable for an organisation). These two sources are enabled by formal mechanisms such as project governance agreements and contracts. Two other informal sources are cultural (i.e., expertise and ownership of information); and social capital (i.e., the access to various networks). Mintzberg's original roles of direct leadership, figurehead, and spokesperson seem to require economic and symbolic capital sources to enable the execution of ceremonial duties and exchange information with external organisations. However, boundary spanners in combined utility streetworks lack the economic resources and do not have the structural position to fulfil these formal tasks. Consequently, utility coordinators cannot lead directly by hiring or recruiting crew, nor can they dictate other stakeholders to prioritise and mobilise specific construction methods. Similarly, the figurehead role requires that organisations permit the boundary spanner to fulfil ceremonial duties, such as, for example, signing off documents. Again, however, the absence of the economic resources and a structural position that grants them the symbolic capital inhibit them from executing this task.

Also, scarcity of the resource allocator, entrepreneur, and negotiator roles could be explained by the lacking formal governance agreements and contracts between utility companies. These instances of economic capital are required to enforce alignment between the distinctive, independent project organisations that develop various parts of the overall master construction plan in combined utility streetworks. Boundary spanners do not have the authority to claim and allocate such economic resources themselves. Further, entrepreneurial roles should ideally help to effectively deal with changes in the organisational environment. In utility projects, such changes can be process hiccups such as, for example, delays due to unexpected ground conditions and damage due to cable strike incidents. The lack of a formal decision-making mandate for utility coordinators hampers them in revising project plans under these conditions. In other words, they cannot autonomously make schedule changes on behalf of all utility owners, and face ambiguity about the responsibilities that various stakeholders have when dealing with surprises. Eventually, this hampers a swift development of delay mitigation plans.

As a consequence of the lacking economic and social capital, boundary spanners in utility streetworks resort to cultural and social capital to facilitate the formal roles discussed above (e.g., disturbance handler and resource allocator). They rely on informational and interpersonal roles to streamline operational processes. This dynamic is also visible in the literature that states the increasing importance of informal management 
and liaison roles in a network context (Burström and Jacobsson, 2013), and the complementary and reciprocal relationship between informal and formal coordination mechanisms (Bygballe et al., 2016; Cao and Lumineau, 2015).

All in all, the findings contribute to the literature in three ways. First, by outlining what utility coordinators do specifically in their everyday work life, this study contributes to the practice turn in organisation studies. The practice turn calls for the exploration of the lived-experiences of individuals in organisations. Such studies should recognise the value of studying the relationship between microlevel activities and their societal context (Vaara and Whittington, 2012; Whittington, 2006) because this whole of behavior-and-context develops a more nuanced understanding about the individual actions in their institutional environment (Korica et al., 2017). Our study of coordination in combined utility streetworks highlights this intricate relationship between everyday practices and the enabling role of their surrounding environment.

A second contribution is the application case of Mintzberg $(1973,1990)$ to contemporary management contexts, which comprise of informal activities and multiple distributed organisations. The setting of combined utility streetworks allowed us to extend the application of Mintzberg's framework to networked projects, and understand boundary spanning in these largely informally coordinated contexts. This application of Mintzberg thus adds a distinctive case to a line of recent studies into the nature of managerial work in organisations (Arman et al., 2009; Matthaei, 2010; Røyrvik, E.A., 2011; Tengblad, 2006).

Based on these findings and reflections, we develop as a third contribution two statements about coordination in networked project settings. First, we posit that utility coordinators have a process catalyzer role rather than being an individual who intervenes (i.e., makes own decisions) with the management of project designs, budgets, and schedules. The success of this catalyzer role relies on coordinators' subject expertise as well as their awareness of involved stakeholders and their plans (i.e., their cultural capital). They shape this knowledge based on information and dissemination roles (i.e., their social capital). These roles require less formal hierarchy and can, therefore, empower the coordinator to become a key figure in the alignment between stakeholders. Formulated as a testable proposition this becomes: the greater the abilities of utility coordinators to access and share information across their network, the more they can influence decision-making outcomes about project content, budget, and schedules. Future research could investigate the extent to which utility coordinators use their expertise and informational roles to influence decision-making outcomes.

With this, our second proposition becomes that studied boundary spanners are placed in a coordination vacuum where there is no formal acknowledgement of their position. Since leadership, figurehead, and decision-making roles require a formal powerbase, they are not well developed in networked project settings. The lack of formal mechanisms between the distinctive project organisations in combined utility streetworks, limit coordinators' decision authority, and decrease their ability to enforce stakeholder alignment. Future research could explore how the lack of these roles problematizes the successful execution of, and decision making in combined utility streetworks. When we formulate this as a testable proposition, this statement becomes: the lack of formal coordination instruments inhibits the utility coordinator to fulfil leadership, figurehead, and decision-making roles.

We finally elaborate on the limitations, future research steps, and implications of this study. For one, the use of structured and ethnographic interview techniques seemed adequate to develop the first conceptualization of utility coordination in a networked project. We identified recurrent instances of coordination roles in the transcripts of the eight respondents. This suggests that we reached empirical saturation and that reliable conclusions can be drawn. We argue, however, that a larger set of interviews can help to further strengthen this claim. We, therefore, suggest that additional interviews and observations of performed coordination in practice would be needed in the future to advance understanding of the complex phenomenon of boundary spanning in networked projects. 
Second, our study included respondents with varying education levels, experiences, employers, and work domains (see Table 2). Literature shows that such backgrounds may influence the position and role of a boundary spanner as well. Shorter length-of-tenure, for example, influences the acceptance of boundary spanners by the network that they represent (Honig, 2006). Further, boundary spanners may need to adopt conflicting roles (Levina and Vaast, 2005). Boundary spanners with a gatekeeper role, for example, serve a different role that again is different when they are representative, advisor (Friedman and Podolny, 1992), scout, or ambassador (Ancona and Caldwell, 1992). Moreover, boundary spanners may prioritise the stakes of one organisation over the other when they feel discomfort to span across many organisations (Wiesenfeld and Hewlin, 2003). When an individual needs to fulfil multiple boundary spanning roles, this may lead to inefficiencies and role conflict (Friedman and Podolny, 1992; Levina and Vaast, 2005). Although our data do not provide evidence of significant differences between practices of respondents or conflicts between adopted roles, we recommend that future research addresses how the diverse backgrounds of utility coordinators influence the adoption of their roles.

Third, this study does not provide any proof of causality between the nature of coordination roles, and their impact on project performance. Although we logically assume that the respondents' activities helped to achieve alignment and coordination, our goal was not to investigate how these contributed to overall project performance. Like in other coordination studies (Cicmil et al., 2006; Savelsbergh et al., 2016), this study and does not intend to infer causality or define 'best practices'. It is suggested that consecutive research steps include other methods such as surveys to better understand what utility coordinators define as best practice for stakeholder alignment in their domain.

This study also has practical implications for the coordination in networked projects. Specifically, the utility sector benefits from this study since it demonstrates that coordination voids in combined utility streetworks are largely bridged through informational and interpersonal roles. Ambiguity about the responsibility for a spokesperson, figurehead, and decision-making tasks especially complicate alignment during moments where improvised action is urgently needed to avoid project delay. These situations occur onsite when ground conditions are not like initially expected; when utilities are damaged; or, when weather conditions obstruct work processes. Understanding these role complications upfront may help the boundary spanners to anticipate risks. We also expect that the identified boundary spanning roles help the sector to replace their persisting assumption that utility streetworks are unified project hierarchies with a more realistic understanding of the networked project concept. This may help the sector shape new governance structures and develop utility coordinators' capabilities to fulfil informal roles. Ultimately this contributes to improving boundary spanning in networked projects.

\section{Conclusion}

Multi-stakeholder engineering processes in contemporary networked project settings are hard to coordinate. In some situations, the lack of formal control mechanisms and shared goals complicates the alignment between stakeholders in these networks. Combined utility streetworks, for example, physically tie together the organisations that own different types of buried infrastructure under public roads. While buried utilities are co-located in the underground, their owners have distinctive maintenance policies, priorities, and goals. Consequently, owners of each utility type create a distinctive project organisation as they often all hire their own dedicated contractor. Although the multiple project hierarchies come together at the same physical space, they are not collectively aligned by formal mechanisms such as project governance contracts or a clear hierarchical structure. Instead, they form what can be called networked project organisations (Chinowsky et al., 2010).

The institutional context of utility streetworks constitutes a modern management setting in which coordinators deploy a variety of roles to align stakeholders. Typically, a combination of informal and formal coordination instruments enables these 
roles. However, since formal instruments are largely absent in combined utility streetworks this complicates the alignment of utility engineering and construction operations. To explore how coordination in this challenged networked project context takes place, this study identifies and adapts Mintzberg's seminal model of informational, interpersonal, and decisional roles (Mintzberg, 1973,Mintzberg, 1990). In specific, it extends the conceptual notion of boundary spanning to the intra-organisational setting of networked projects. By using combined utility streetworks as a case, this study finally reflected on how the context of networked projects influences the adoption of boundary spanning roles.

To achieve this goal, we conducted seven ethnographic interviews with utility coordinators who manage the alignment between project organisations in combined utility streetworks. Three rounds of explorative and qualitative analysis followed the principles of open and axial coding (Strauss and Corbin, 1994) and helped identify verbatim quotes and match these with management role definitions from the literature. This resulted in a refined and amended version of Mintzberg's original management model. The new model includes a second tier of empirically derived coordination categories that describe how coordinators align participants in a networked project context. Examples are the roles that identify and involve stakeholders; facilitate formal processes; create a collective memory; update stakeholders about onsite progress; inspect construction sites; and, solve operational problems. The role categories show that informational and interpersonal roles were performed more often than decisional roles in the context of utility works.

All in all, this study makes another step into the research of informal coordination in fragmented networked projects. This follows the calls in the practice turn in the organisation science literature to explore in detail what individuals in organisations actually do from day to day and to understand how social and institutional contexts influence this behaviour. Specifically, we developed an understanding of how coordination takes place when traditional control mechanisms such as structure, formal contracts, and hierarchy are largely absent. Second, through the application of Mintzberg's lens, we extend the concept of boundary spanning to networked projects and define which roles this setting enables and constrains. Third, the findings lead to two propositions about the utility coordinator. These are (1) the greater the abilities of utility coordinators to access and share information across their network, the more they can influence decision-making outcomes about project content, budget, and schedules, and (2) the lack of formal coordination instruments inhibits the utility coordinator to fulfil leadership, figurehead, and decision making roles. Eventually, our findings help practice define the roles needed for utility coordination, and may enable practitioners to train and develop those roles to enhance alignment within the sector.

\section{Acknowledgments}

We greatly acknowledge the interview respondents for their participation in this research and thank Stichting Pioneering for financing this study. The funding source was not involved in the collection, analysis, and interpretation of the data.

\section{ORCID}

Léon L olde Scholtenhuis (10 http://orcid.org/00000001-5361-6106

André G Dorée (D) http://orcid.org/0000-00021825-0097

\section{References}

Aagaard, A., Eskerod, P. and Madsen, E.S. (2015), "Key drivers for informal project coordination among sub-contractors: a case study of the offshore wind energy sector", International Journal of Managing Projects in Business, Vol. 8, pp. 222-240.

Ahola, T., Vuori, M. and Viitamo, E. (2017), "Sharing the burden of integration: an activity-based view to integrated solutions provisioning", International Journal of Project Management, Vol. 35 No. 6, pp. 1006-1021. 10.1016/j.ijproman.2017.05.002

Ancona, D.G. and Caldwell, D.F. (1992), "Bridging the boundary: external activity and performance in organizational teams", Administrative Science Quarterly, Vol. 37 No. 4, pp. 634-665. 10.2307/2393475 
Anvuur, A.M. and Kumaraswamy, M.M. (2012), "Measurement and antecedents of cooperation in construction", Journal of Construction Engineering and Management, Vol. 138 No. 7, pp. 797-810. 10.1061/(ASCE)CO.1943-7862.0000498

Arman, R., Dellve, L., Wikström, E. and Törnström, L. (2009), "What health care managers do: applying Mintzberg's structured observation method", Journal of Nursing Management, Vol. 17 No. 6, pp. 718-729. 10.1111/j.1365-2834.2009.01016.x

Bauman, L.J. and Adair, E.G. (1992), “The use of ethnographic interviewing to inform questionnaire construction", Health Education Quarterly, Vol. 19 No. 1, pp. 9-23. 10.1177/109019819201900102

Bechky, B.A. (2006), "Gaffers, gofers, and grips: Rolebased coordination in temporary organizations", Organization Science, Vol. 17 No. 1, pp. 3-21. 10.1287 /orsc. 1050.0149

Blackburn, S. (2002), "The project manager and the project-network", International Journal of Project Management, Vol. 20 No. 3, pp. 199-204. 10.1016/ S0263-7863(01)00069-2

Bourdieu, P. and Wacquant, L.J. (1992), An invitation to reflexive sociology. Chicago: University of Chicago Press. 9780226067414.

Bresnen, M. (2007), "The practice turn in organisational studies and construction management research". In: Hughes W, ed, CME 25 Conference: Construction Management and Economics, Past, Present and Future, 2007 Reading. pp. 1747-1756.

Bresnen, M. and Marshall, N. (2002), "The engineering or evolution of co-operation? A tale of two partnering projects", International Journal of Project Management, Vol. 20 No. 7, pp. 497-505. 10.1016/ S0263-7863(01)00043-6

Brion, S., Chauvet, V., Chollet, B. and Mothe, C. (2012), "Project leaders as boundary spanners: relational antecedents and performance outcomes", International Journal of Project Management, Vol. 30 No. 6, pp. 708-722. 10.1016/j.ijproman.2012.01.001

Brown, J.S. and Duguid, P. (2001), "Knowledge and organization: a Social-Practice perspective", Organization Science, Vol. 12 No. 2, pp. 198-213. 10.1287/orsc.12.2.198.10116

Burström, T. and Jacobsson, M. (2013), "The informal liaison role of project controllers in new product development projects", International Journal of Managing Projects in Business, Vol. 6 No. 3, pp. 410-424. 10.1108/IJMPB-10-2011-0069

Burtwell, M.H., Evans, M. and Mcmahon, W. (2006), Minimising street works disruption: the real costs of street works to the utility industry and society. UK: Water Industry Research Limited.
Bygballe, L.E., Dewulf, G. and Levitt, R.E. (2015), "The interplay between formal and informal contracting in integrated project delivery", Engineering Project Organization Journal, Vol. 5 No. 1, pp. 22-35. 10.1080/21573727.2014.992014

Bygballe, L.E., Swärd, A.R. Vaagaasar, A.L. and Vaagaasar, A.L. (2016), "Coordinating in construction projects and the emergence of synchronized readiness", International Journal of Project Management, Vol. 34 No. 8, pp. 1479-1492. 10.1016/j. ijproman.2016.08.006

Cao, Z. and Lumineau, F. (2015), "Revisiting the interplay between contractual and relational governance: a qualitative and meta-analytic investigation", Journal of Operations Management, Vol. 33-34 No. 1, pp. 15-42. 10.1016/j.jom.2014.09.009

Certeau, M, de. (1984), The Practice of Everyday Life. Berkeley: University of California Press.

Chan, A.T.S. and Chan, E.H.W. (2005), "Impact of perceived leadership styles on work outcomes: case of building professionals", Journal of Construction Engineering and Management, Vol. 131 No. 4, pp. 413-422. 10.1061/(ASCE)07339364(2005)131:4(413)

Chinowsky, P., Taylor, J.E. and Di Marco, M. (2011), "Project network interdependency alignment: new approach to assessing project effectiveness", Journal of Management in Engineering, Vol. 27 No. 3, pp. 170-178. 10.1061/(ASCE)ME.19435479.0000048

Chinowsky, P.S., Diekmann, J. and O’Brien, J. (2010), "Project organizations as social networks", Journal of Construction Engineering and Management, Vol. 136 No. 4, pp. 452-458. 10.1061/(ASCE)CO.19437862.0000161

Chinowsky, P. and Taylor, J.E. (2012), "Networks in engineering: an emerging approach to project organization studies", Engineering Project Organization Journal, Vol. 2 No. 1-2, pp. 15-26. 10.1080/21573727.2011.635647

Chinowsky, P.S. and Taylor, J.E. (2007), Project networks: Leadership, learning, and development, Vol. 54.

Cicmil, S., Williams, T., Thomas, J. and Hodgson, D. (2006), "Rethinking project management: researching the actuality of projects", International Journal of Project Management, Vol. 24 No. 8, pp. 675-686. 10.1016/j.ijproman.2006.08.006

Clough, R.H., Sears, G.A., Sears, S.K., Segner, R.O. and Rounds, J.L. (2015), Construction contracting: a practical guide to company management. New Jersey, USA: John Wiley \& Sons.

Engineering Project Organization Journal

(C) 2021 Engineering Project Organization Society www.epossociety.org 
Davies, A. and Brady, T. (2000), "Organisational capabilities and learning in complex product systems: towards repeatable solutions", Research Policy, Vol. 29 No. 7-8, pp. 931-953. 10.1016/S00487333(00)00113-X

Davies, A. and Brady, T. (2016), "Explicating the dynamics of project capabilities", International Journal of Project Management, Vol. 34 No. 2, pp. 314-327. 10.1016/j.ijproman.2015.04.006

Davies, A. and Mackenzie, I. (2014), "Project complexity and systems integration: constructing the London 2012 Olympics and Paralympics games", International Journal of Project Management, Vol. 32 No. 5, pp. 773-790. 10.1016/j.ijproman.2013.10.004

de Bruijne, M. and van Eeten, M. (2007), "Systems that should have failed: critical infrastructure protection in an institutionally fragmented environment", Journal of Contingencies and Crisis Management, Vol. 15 No. 1, pp. 18-29. 10.1111/j.14685973.2007.00501.x

de Holan, P.M. and Mintzberg, H. (2004), "Management as Life's Essence: 30 Years of the Nature of Managerial Work", Strategic Organization, Vol. 2, pp. 205-212. 10.1177/1476127004042844

Di Marco, M.K., Taylor, J.E. and Alin, P. (2010), "Emergence and role of cultural boundary spanners in global engineering project networks", Journal of Management in Engineering, Vol. 26 No. 3, pp. 123-132. 10.1061/(ASCE)ME.1943-5479.0000019

Dougherty, D. (1992), "A practice-centered model of organizational renewal through product innovation", Strategic Management Journal, Vol. 13 No. S1, pp. 77-92. 10.1002/smj.4250131007

Fellows, R. and Liu, A.M.M. (2012), "Managing organizational interfaces in engineering construction projects: addressing fragmentation and boundary issues across multiple interfaces", Construction Management and Economics, Vol. 30 No. 8, pp. 653-671. 10.1080/01446193.2012.668199

Fenton, C. and Langley, A. (2011), "Strategy as practice and the narrative turn", Organization Studies, Vol. 32 No. 9, pp. 1171-1196. 10.1177/0170840611410838

Friedman, R.A. and Podolny, J. (1992), "Differentiation of boundary spanning roles: labor negotiations and implications for role conflict", Administrative Science Quarterly, Vol. 37 No. 1, pp. 28-47. $10.2307 / 2393532$

Galbraith, J.R. (1973), Designing complex organizations. Boston, MA: Addison-Wesley.

Galbraith, J.R. (1977), Organization design. Reading, MA: Addison-Wesley.
Hodgson, D.E. (2004), "Project work: the legacy of bureaucratic control in the post-bureaucratic organization", Organization, Vol. 11 No. 1, pp. 81-100. 10.1177/1350508404039659

Honig, M.I. (2006), "Street-level bureaucracy revisited: frontline district central-office administrators as boundary spanners in education policy implementation", Educational Evaluation and Policy Analysis, Vol. 28 No. 4, pp. 357-383. 10.3102/01623737028004357

Hossain, L. (2009a), "Communications and coordination in construction projects", Construction Management and Economics, Vol. 27 No. 1, pp. 25-39. $10.1080 / 01446190802558923$

Hossain, L. (2009b), "Effect of organisational position and network centrality on project coordination", International Journal of Project Management, Vol. 27 No. 7, pp. 680-689. 10.1016/j.ijproman.2008.11.004

Hussain, R.S., Enoch, M., Ruikar, K., Brien, N. and Gartside, D. (2016), "Street work policy in England, UK: insights from stakeholders", Infrastructure Asset Management, Vol. 3 No. 2, pp. 61-70. 10.1680/ jinam.16.00002

Iorio, J. and Taylor, J.E. (2014), "Boundary object efficacy: the mediating role of boundary objects on task conflict in global virtual project networks", International Journal of Project Management, Vol. 32 No. 1, pp. 7-17. 10.1016/j.ijproman.2013.04.001

Iorio, J. and Taylor, J.E. (2015), "Precursors to engaged leaders in virtual project teams", International Journal of Project Management, Vol. 33 No. 2, pp. 395-405. 10.1016/j.ijproman.2014.06.007

Jha, K.N. and Iyer, C.K. (2006), "What attributes should a project coordinator possess?" Construction Management and Economics, Vol. 24 No. 9, pp. 977-988. 10.1080/01446190600781826

Jha, K.N. and Iyer, K.C. (2007), "Commitment, coordination, competence and the iron triangle", International Journal of Project Management, Vol. 25 No. 5, pp. 527-540. 10.1016/j.ijproman.2006.11.009

Joshi, A., Pandey, N. and Han, Guohong (Helen). (2009), "Bracketing team boundary spanning: an examination of task-based, team-level, and contextual antecedents", Journal of Organizational Behavior Vol. 30 No. 6, pp. 731-759. 10.1002/job.567

Kamminga, Y.P. (2008), Towards effective governance structures for contractual relations. Tilburg: Tilburg University.

Korica, M., Nicolini, D. and Johnson, B. (2017), “In search of 'managerial work': Past, present and future of an analytical category", International 
Journal of Management Reviews, Vol. 19 No. 2, pp. 151-174. 10.1111/ijmr.12090

Kurke, L.B. and Aldrich, H.E. (1983), "Note-Mintzberg was right!: a replication and extension of the nature of managerial work", Management Science, Vol. 29 No. 8, pp. 975-984. 10.1287/mnsc.29.8.975

Larson, M. and Wikström, E. (2007), "Relational interaction processes in project networks: the consent and negotiation perspectives", Scandinavian Journal of Management, Vol. 23 No. 3, pp. 327-352. 10.1016/j.scaman.2007.06.001

Lawrence, P.R., Lorsch, J.W. and Garrison, J.S. (1967), Organization and environment: Managing differentiation and integration. Boston, MA: Harvard University Press.

Lee, S. and Sawang, S. (2016), "Unpacking the impact of attachment to project teams on boundaryspanning behaviors", International Journal of Project Management, Vol. 34 No. 3, pp. 444-451. 10.1016/j.ijproman.2015.12.003

Levina. and Vaast. (2005), "The emergence of boundary spanning competence in practice: implications for implementation and use of information systems", MIS Quarterly, Vol. 29 No. 2, pp. 335-363. $10.2307 / 25148682$

Long, J.C., Cunningham, F.C. and Braithwaite, J. (2013), "Bridges, brokers and boundary spanners in collaborative networks: a systematic review", BMC Health Services Research, Vol. 13 No. 1, 158. 10.1186/1472-6963-13-158

Love, P.E.D., Zhou, J., Edwards, D.J., Irani, Z. and Sing, C.-P. (2017), "Off the rails: the cost performance of infrastructure rail projects", Transportation Research Part A: Policy and Practice, Vol. 99, pp. 14-29. 10.1016/j.tra.2017.02.008

Manning, S. (2005), "Managing project networks as dynamic organizational forms: learning from the TV movie industry", International Journal of Project Management, Vol. 23 No. 5, pp. 410-414. 10.1016/j. ijproman.2005.03.006

Matthaei, E.E. (2010), The nature of executive work: a case study. Wiesbaden, Germany: Gabler Verlag.

Mintzberg, H. (1973), The nature of managerial work. New York: Harper \& Row.

Mintzberg, H. (1980), "Structure in 5's: A Synthesis of the Research on Organization Design", Management Science, Vol. 26 No. 3, pp. 322-341. 10.1287/ mnsc.26.3.322

Mintzberg, H. (1990), “The Manager's Job”, Harvard Business Review, pp. 1-13.

Miterev, M., Mancini, M. and Turner, R. (2017), "Towards a design for the project-based organization", International Journal of Project Management,
Vol. 35 No. 3, pp. 479-491. 10.1016/j.ijproman.2016.12.007

Momeni, K. and Martinsuo, M. (2019), “Going downstream in a project-based firm: integration of distributors in the delivery of complex systems", International Journal of Project Management, Vol. 37 No. 1, pp. 27-42. 10.1016/j.ijproman.2018.09.007

Müller, R. and Turner, R. (2010), "Leadership competency profiles of successful project managers", International Journal of Project Management, Vol. 28 No. 5, pp. 437-448. 10.1016/j.ijproman.2009.09.003

Najafi, M. (2005), Trenchless technology: pipeline and utility design, construction, and renewalMcGraw Hill Professional.

Orlikowski, W.J. (2000), "Using technology and constituting structures: a practice lens for studying technology in organizations", Organization Science, Vol. 11 No. 4, pp. 404-428. 10.1287/orsc.11.4.404.14600

Oswald, D. and Dainty, A. (2020), "Ethnographic research in the construction industry: a critical review", Journal of Construction Engineering and Management, Vol. 146 No. 10, p. 03120003. 10.1061/(ASCE)CO.1943-7862.0001917

Ozorovskaja, R., Voordijk, J.T. and Wilderom, C.P.M. (2007), "Leadership and cultures of Lithuanian and Dutch construction firms", Journal of Construction Engineering and Management, Vol. 133 No. 11, pp. 900-911. 10.1061/(ASCE)07339364(2007)133:11(900)

Pauget, B. and Wald, A. (2013), "Relational competence in complex temporary organizations: the case of a French hospital construction project network", International Journal of Project Management, Vol. 31 No. 2, pp. 200-211. 10.1016/j.ijproman.2012.07.001

Polzer, J.T. and Nicholson, N. (1995), Role. Encyclopedic dictionary of organizational behavior. Cambridge MA: Blackwell Publishers Inc.

Røyrvik, E.A.. (2011), The allure of capitalism: An ethnography of management and the global economy in crisis. NY, USA: Berghahn Books.

Saulwick, J. (2014), Sydney light rail line costs blow out to $\$ 2.2$ billion $-\$ 600$ million more than budgeted. Sydney: Morning Herald.

Savelsbergh, C.M.J.H., Havermans, L.A. and Storm, P. (2016), "Development paths of project managers: what and how do project managers learn from their experiences?" International Journal of Project Management, Vol. 34 No. 4, pp. 559-569. 10.1016/j. ijproman.2016.02.005

Sherman, J.D. and Keller, R.T. (2011), "Suboptimal assessment of interunit task interdependence: modes of integration and information processing for coor-

Engineering Project Organization Journal

(C) 2021 Engineering Project Organization Society www.epossociety.org 
dination performance", Organization Science, Vol. 22 No. 1, pp. 245-261. 10.1287/orsc. 1090.0506

Spradley, J. (1979), The ethnographic interview. New York: Holt, Rinehart and Winston.

Steenhuisen, B., Dicke, W. and de Bruijn, H. (2009), “'“Soft” Public Values in Jeopardy: Reflecting on the Institutionally Fragmented Situation in Utility Sectors", International Journal of Public Administration, Vol. 32 No. 6, pp. 491-507. 10.1080/01900690902861753

Stjerne, I.S., Söderlund, J. Minbaeva, D. and Minbaeva, D. (2019), "Crossing times: temporal boundaryspanning practices in interorganizational projects", International Journal of Project Management, Vol. 37 No. 2, pp. 347-365. 10.1016/j.ijproman.2018.09.004

Strauss, A. and Corbin, J. (1994), "Grounded theory methodology", Handbook of qualitative research, Vol. 17, pp. 273-285.

Strauss, A.L. and Corbin, J.M. (1990), Basics of qualitative research: Grounded Theory Procedures and Techniques. California, USA: Sage Publications Inc.

Tan, Y., Xue, B. and Cheung, Y.T. (2017), "Relationships between main Contractors and Subcontractors and their impacts on main contractor competitiveness: an empirical study in Hong Kong", Journal of Construction Engineering and Management, Vol. 143 No. 7, p. 05017007. 10.1061/(ASCE)CO.19437862.0001311

Tengblad, S. (2006), "Is there a 'new managerial work'? A comparison with henry mintzberg's classic study 30 years later", Journal of Management Studies, Vol. 43 No. 7, pp. 1437-1461. 10.1111/j.14676486.2006.00651.x

Tsai, W. (2002), "Social structure of "coopetition" within a multiunit organization: Coordination, competition, and intraorganizational knowledge sharing”, Organization Science, Vol. 13 No. 2, pp. 179-190. 10.1287/orsc.13.2.179.536

Tushman, M.L. and Katz, R. (1980), "External communication and project performance: an investigation into the role of gatekeepers", Management Science, Vol. 26 No. 11, pp. 1071-1085. 10.1287/ mnsc.26.11.1071
Urup, L. and Koch, C. (2014), "Recasting coordination: a theoretical review in the context of design-build project organisations", Procs 30th Annual ARCOM Conference, Porthsmouth. 815-824.

Vaara, E. and Whittington, R. (2012), "Strategy-asPractice: taking social practices seriously", Academy of Management Annals, Vol. 6 No. 1, pp. 285-336. 10.5465/19416520.2012.672039

Vilventhan, A. and Kalidindi, S.N. (2016), "Interrelationships of factors causing delays in the relocation of utilities: a cognitive mapping approach", Engineering, Construction and Architectural Management, Vol. 23, pp. 349-368.

Wang, Y., Chen, Y., Fu, Y. and Zhang, W. (2017), “Do prior interactions breed cooperation in construction projects? the mediating role of contracts", International Journal of Project Management, Vol. 35 No. 4, pp. 633-646. 10.1016/j.ijproman.2017.02.019

Whittington, R. (2003), "The work of strategizing and organizing: for a practice perspective", Strategic Organization, Vol. 1, pp. 117-125. 10.1177/147612700311006

Whittington, R. (2006), "Completing the practice turn in strategy research", Organization Studies, Vol. 27 No. 5, pp. 613-634. 10.1177/0170840606064101

Wiesenfeld, B.M. and Hewlin, P.F. (2003), "Splintered identity and organizational change: The predicament of boundary spanning managers". In: Mannix M, Neale A, Plzer J. T, eds, Research on Managing Groups and Teams. Bingley, UK: Elsevier Science Ltd.

Winch, G.M. (2014), "Three domains of project organising", International Journal of Project Management, Vol. 32 No. 5, pp. 721-731. 10.1016/j. ijproman.2013.10.012

Zelkowicz, A., Iorio, J. and Taylor, J.E. (2015), "Exploring the role of cultural boundary spanners at complex boundaries in global virtual AEC networks", Journal of Information Technology in Construction, Vol. 20, pp. 385-398.

Zhang, L. and Fan, W. (2013), "Improving performance of construction projects: A project manager's emotional intelligence approach", Engineering, Construction and Architectural Management, Vol. 20, pp. 195-207. 